\title{
Genetic epidemiology on casual theories and pathogenesis of type 2 diabetes mellitus
}

\author{
Carlos Jonnathan Castro-Juárez¹, Sergio Alberto Ramírez-García ${ }^{1}$, Nemesio Villa-Ruano and \\ Diana García-Cruz ${ }^{2}$ \\ ${ }^{1}$ Institute of Public Health Research, Universidad de la Sierra Sur, Miahuatlán de Porfirio Díaz, Oax.; ${ }^{2}$ Instituto de Genética Humana Dr. Enrique \\ Corona Rivera, Department of Molecular Biology and Genomics, University Center of Health Sciences, Universidad de Guadalajara, Guadalajara, \\ Jal. Mexico
}

\begin{abstract}
Diabetes mellitus type 2 (DM2) is a worldwide public health problem. The etiology of the disease is multifactorial and is characterized by great heterogeneity of metabolic disorders. The most common are the insufficient production of insulin, insulin resistance and impaired incretin system. The specialist must understand the multi-causal nature of DM2 in the post-genomic era. This nature is determined by the additive effect of genes and environment, so there is no simple genetic epidemiological model to explain the inheritance pattern. Hence the need to establish the proportion of disease that is determined by genes and the contribution of environmental factors, the combination of which regulates the threshold or tolerance level for diabetes development. Given this complexity in DM2 in this work are discussed the various existing theories of causality of this disease, which will permit us to understand the interaction between the environment and the human genome, and also to know how risk factors or predisposition to this disease influence, laying the grounds that delimit environment interaction with the genome.
\end{abstract}

KEY WORDS: Environment. Diabetes mellitus type 2. Genome. Pathogenesis. Public health.

\section{Introduction}

The incidence and prevalence of type 2 diabetes mellitus (DM2) has been reported in up to $90 \%$ of total diabetes cases $^{1,2}$. The World Health Organization has predicted that by the year 2025 there will be more than 300 million diabetics in the world and, out of them, 40 million will correspond to Latin America and the Caribbean. Half of them will not be diagnosed before chronic complications beguin ${ }^{3,4}$. There are some indigenous populations where the prevalence of DM2 is lower owing to environmental factors such as the diet (endemic/traditional), which acts as a protecting factor $^{5}$, but there is a process of lack of education with regard to urban nutrition, which considerably increases the prevalence in rural indigenous communities ${ }^{6}$.
DM2 is a disease of multifactorial etiology, characterized by great heterogeneity of molecular defects, such as insufficient insulin production by pancreatic $\beta$ cells, insulin resistance and incretin system defects, which translate into alterations in the metabolism of fats and proteins ${ }^{4,7-10}$. There can be overlapping with diabetes of the young mature adult, produced by pancreatic $\beta$ cells genetic defects, or else there can be overlapping endocrinopathies, infections, gestational diabetes mellitus and autoimmune diabetes forms ${ }^{8}$. It is part of the Down, Klinefelter and Turner syndromes, among others, natural evolution ${ }^{8,9}$.

Epidemiologically, DM2 occurs more commonly in the adult population ${ }^{9,11}$. However, there are reports showing an early age of onset, between 18 and before 40 years $^{12,13}$. As a whole, these works provide evidence of variable onset age. Diabetes has been

\author{
Correspondence: \\ Diana García-Cruz \\ Sierra Mojada, 950, Edificio P, Nivel 2 \\ Col. Independencia \\ C.P. 44340, Guadalajara, Jal., México \\ E-mail: dianagarcr@hotmail.com
}

Date of reception: 05-12-2016

Date of acceptance: 23-03-2017

DOI://dx.doi.org/10.24875/GMM.M18000086
Gac Med Mex. 2017;153:784-793

Contents available at PubMed www.gacetamedicademexico.com 
proposed to be related to partial deficit of and resistance to insulin, as well as to the response to oral hypoglycemic agents ${ }^{9,11}$. It is a complex disorder owing to an association with variable degrees of hereditary predisposition and the participation of environmental risk factors, such as stress, overweight, central or abdominal obesity, sedentary lifestyle, hypercaloric diet, saturated fat and simple carbohy-

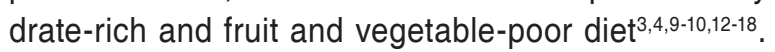

\section{Type 2 diabetes mellitus causality theories}

The analysis about the pathogenesis of DM2 provides an overview of the interaction of the environment with the human genome and risk or predisposing factors, which should be considered by public health experts when designing epidemiological studies ${ }^{7,8}$. Genetic and molecular heterogeneity of diabetes is a reflection on DM2 multifactorial nature, which directly impacts on the evolution of chronic complications and treatment response. Therefore, there is no simple genetic model that explains familial aggregation. Studies establishing the percentage of disease that is determined by genes and the contribution of environmental factors are required ${ }^{19}$. The present work discusses most theories on the origin of diabetes, from environmental studies in the decade of 1960 to the molecular biomedical investigations in 2016.

\section{Thrifty genotype theory}

In 1962, J.R. Neel proposed the "thrifty genotype" theory, which explains that DM2 is an evolution process of the genes of metabolism. It claims that there is a thrifty genotype, which in the Paleolithic population (hunter-gatherers) translated into an efficient metabolic system to assimilate nutrients and store them in the form of fat in periods of food abundance, which warranted their survival in periods of famine during the Fourth Glaciation. The population that had such adaptive genotype lived in that primitive society. Current heirs of these population are Latin American post-colonial societies that, owing to the transition into industrialized societies with high intake of energetic foods (abundant intake) suffer a negative selection that enables the appearance of obesity and diabetes. Neel referred that this process occurred in Europe in the $18^{\text {th }}$ century, where only individuals without the thrifty genotype survived ${ }^{20}$. The thrifty genotype comprises many genes, and it is a line that has to be followed in diabetes epidemiology in Latin America, since it explains diabetes in post-colonial societies, which show abundant consumption of highly energetic foods. Many of these genes encode growth factors, hormone receptors, vascular regulators and regulators of the hepatic metabolism of lipids, among others. Formerly, the APOE gene had been proposed as part of that genotype ${ }^{8}$. Currently, we have explored the LRP2, HPSE and ELMO1 genes in the Mexican population. The proposed genes include HPSE, which encodes heparanase, an enzyme that regulates extracellular matrix heparan sulfate metabolism, important in the binding of apolipoprotein $E$ to the vascular endothelium, the alteration of which favors atherogenesis and diabetes-associated vascular dysfunction; $L R P 2$, which encodes a lipoprotein receptor, which works through a mechanism of renal endocytosis, since its deregulation drives to dyslipidemia and diabetes; and ELMO1K, a cytokinesis regulator in the centrosome, the deregulation of which leads to diabetes. In association studies, these genes have demonstrated their effect on the risk for longstanding diabetes, the clinical phenotype of which is insulin resistance. Interaction of these pleiotropic genes in association studies with their polymorphisms can explain the risk for the development of hypertension, dyslipidemia, fatty liver, overweight and obesity, which are stages previous to $\mathrm{DM}^{21-24}$.

\section{Insulin resistance or the not so thrifty gene}

Genetic information was slowly shaped, with no big important changes across each one of the evolutionary process stages, from Ardipithecus ramidus, of arboreal life, to current Homo sapiens, with our nutritional requirements thus being determined. During these evolutionary stages, the "thrifty genotype" emerged, expressed by leptin resistance, as well as the "not so thrifty genotype" characterized by insulin resistance. Muscle insulin resistance was key to survive in periods of famine, which were quite frequents for Homo ergaster. Hepatic and renal gluconeogenesis enabled maintaining blood glucose at normal levels during fasting; this adjustment is much more effective if skeletal muscle possesses insulin resistance, since this tissue is forced to use fatty acids originating in adipose tissue reserves, with glucose in turn being reserved for consumption almost exclusively by the brain and red blood cells, since both these tissues are highly dependent on glucose for their metabolic functions ${ }^{20}$. Muscle insulin resistance, by producing high concentrations of circulating insulin, favors triglyceride 
accumulation in the adipose tissue, which favors adipogenesis ${ }^{25}$. To explain this theory, the CPN10 gene has been proposed, which encodes calpain 10, a muscle protease; the heterozygous genotype of its polymorphism SNP43 is related to lower mRNA amounts in striated muscle and proteolysis ${ }^{18}$.

Insulin resistance was the mechanism that allowed Fourth Glaciation migrants surviving during prolonged fasting periods, preserving muscle mass, which enabled them to successfully hunt at first opportunity or being able to flee from predators. Preserving muscle mass meant increasing glycosuria and decreasing proteolysis. Studies on the CPN10 gene support this theory, since it encodes a protease of the muscle cytosolic cistern. In the Pima Indians, homozygous carriers of SMP49 polymorphism G allele show lower amounts of mRNA in striated muscle. Variations in this gene have already been associated with DM2 in Mexican populations. We postulate that variants of the GLUT2 gene (which encodes type 2 glucose transporter and is implicated in renal Fanconi syndrome, a type of hepatorenal glucogenesis with glycosuria, phosphaturia, amino aciduria and mucopolysacchariduria) might support this hypothesis. In an exploratory study in patients with DM2 in a population of southern Mexico, we did not find association of this gene, but it should be further studied, since its product, type 2 glucose transporter, is one of current targets in DM2 treatment, since it is glycosuric ${ }^{2}$.

\section{Thrifty phenotype theory}

The thrifty phenotype hypothesis proposes that both intrauterine and childhood undernutrition can program gene expression to the benefit of survival. The brain is protected over other tissues, which leads to a metabolic programming that is conditioned by bioenergetic substrate scarcity ${ }^{26,27}$. Intrauterine malnutrition, in particular protein deficit, has demonstrated an alteration on the pancreatic function with a decrease in Langerhans cells and a decreased insulin-secreting capability. According to this hypothesis, undernutrition, which is characterized by low birth weight, would elicit an in utero programming that would explain most part of obesity, metabolic syndrome and DM2 in an adult born with low weight for gestational age, and who subsequently is exposed to an environment of alimentary abundance. Moreover, evidence from numerous studies indicates that this programming is not restricted to the first generation ${ }^{18,27,28}$.

\section{Theory of programming (Barker hypothesis)}

This association theory postulates that if there is a stimulus or aggression in utero (intrauterine malnutrition) during a critical period, this produces a temporary or permanent change in the structure and function of the body (fetal programming) ${ }^{29,30}$. Currently, four birth phenotypes related to diseases at adult age have been identified, out of which two explain alterations related to glycemic control. The first pone indicates that slim newborns tend to be insulin resistant when they become adults, and the second short height and high weight infants with lower insulin production, which generates DM2 at adult ages. This gives rise to the hypothesis of fetal origin of disease, which would originate DM2 and chronic conditions owing to fetus adaptation to intrauterine malnutrition ${ }^{31,32}$.

\section{Genomic imprinting}

The human being has a unique epigenetic mark that is partially inherited and partially generated in utero, with changes in adult life $e^{33,34}$. These epigenetic changes are generated by different routes, such as histone and gene methylation, histone acetylation, ubiquitination, sumoylation, phosphorylation, ribosylation, glycosylation and non-coding RNAs. In the conception phase, two moments of switching off and programming of a new gene have been documented to exist: the first moment occurs during gametogenesis and, the second, at pre-implantation, when the genome is demethylated; during these two methylation processes, the epigenetic program becomes vulnerable to alterations generated by the fetal environment, with some theories suggesting that these alterations would generate disorders in adulthood, such as $\mathrm{DM} 2^{35}$. However, recent data indicate that during childhood, adolescence and puberty epigenetic alterations that would affect the endocrine system can also occur, since at these stages there is a relative increase in DNS synthesis and cell growth ${ }^{36,37}$.

Nutrition plays a protective role, but also can trigger these processes. Currently, the decrease in methyl groups' donors (folates, methionine and choline) dietary intake, and the consumption of sulfur-poor diets, have been identified to produce a modification in cysteine formation, thus being associated with a decrease in DNA methylation. However, unlike gene polymorphisms, which are permanent, there environmental 
are not; nevertheless, factors such as stress, little exercise, inadequate diet, inflammatory processes, hyperglycemia, obesity and oxidative stress will condition overexpression of some genes. In addition, something important about errors in the DNA methylation process is that they increase as the subject gets older, thus causing an increase in the risk of suffering from $\mathrm{DM} 2^{38,39}$.

Environmental factors, such as hyperglycemia, which are generated by foods with high glycemic index, contribute to produce toxic compounds by four fundamental pathways: the polyol pathway, the formation of advanced glycation end-products (AGEs), the protein kinase $C$ activation pathway and the hexosamine pathway; this causes higher production of oxygen reactive species (ROS), nitrogen reactive species and $\mathrm{O}_{2}$ - increase, thus generating an oxidative stress situation that leads to pathways directed to epigenetic alterations and apoptosis ${ }^{40}$.

Diverse studies explain that hyperglycemia affects the expression of certain genes and chromatin modifications, as it is the case of the association between the chemical changes of histone $\mathrm{H} 3$ amino-terminal tails and lysine-specific methyltransferase Set7. This expression helps to improve chromatin accessibility and $\beta$-cell genes transcription, which indicates that this is the cause of vascular gene expression in response to previous hyperglycemia episodes ${ }^{40}$. This is supported by findings in an experimental model with sheep that suffered moderate maternal undernutrition, where methylation of gene promoters (POMC) and fetal hypothalamus glucocorticoid receptor were found to be reduced, thus altering energy balance regulation and being associated with DNA methyltransferase lower activity and methylation alteration, as well as with histone acetylation, which generated the hypothesis that hypocaloric or protein-poor diets during pregnancy are implicated in the offspring being programmed towards the development of obesity and $\mathrm{DM}^{41}$.

Another study with monozygotic twins of between 53 and 80 years of age, divergent for DM2, identified $789 \mathrm{CpG}$ sites in skeletal muscle and 1458 in the subcutaneous adipose tissue, which were differentially methylated ${ }^{42}$, with some of them being located in genes as important as PPARGC1A and HNF4A, which could lead to an increase in hepatic glucose production that, in turn, would contribute to increase hyperglycemia risk and, if maintained, to generate insulin resistance and DM2. Volkmar et al. ${ }^{43}$ described a considerable number of hypermethylated genes in
DM2 patients' islets, which participate in pathways that have been identified to preserve $\beta$-cells survival and functioning. It is suggested that these epigenetic mechanisms are implicated in $\beta$-cell dysfunction and DM2 genesis.

With regard to fat consumption, a pattern has been reported in DM2 pathogenesis that suggests that hyperlipidic and hypercaloric diets generate an increase in the production of short chain fatty acids as long chain fatty acids byproduct, which would lead to changes in DNA methylation that cause promotor hypomethylation and pro-inflammatory cytokines deregulation, generating peripheral insulin resistance ${ }^{38}$. These results indicate that several epigenetic mechanisms can be implicated in $\beta$-cell dysfunction and in diabetes pathogenesis, which opens the door to the study of the role of nutrition, oxidative stress and inflammatory processes.

Four birth phenotypes have been currently identified as being associated with diseases at adult age, out of which two explain alterations associated with glycemic control. The first one indicates that slim newborns tend to be resistant to insulin when they become adults, whereas the second correlates low height and high weight infants with lower insulin production, which generated DM2 at adult ages. This theory, somehow forgotten, is closely related to genomic imprinting. Metabolic programming for adult age takes place at last trimester of pregnancy, and is associated with insulin resistance. One of the genes that might be implicated is the gene that codes for aromatase, CYP19A1, since it turns estrogen into androgen in peripheral tissues, such as fatty tissue and muscle, among others. It is associated with a clinical phenotype characterized by virilization, hyperandrogenism, gestational diabetes and insulin resistance, which is a metabolic reprogramming pathophysiogenic mechanism. Some preliminary epidemiological studies, where we have collaborated, in Mexican population with regard to this gene, show their association with DM2 and diabetic retinopathy.

Another line to explore, which requires further study, is the high consumption of saturated fats. Hyperlipidic and hypercaloric diets have been suggested to generate an increase in the production of short chain fatty acids as long chain fatty acids byproducts, which would lead to changes in DNA methylation that cause promoter hypomethylation and pro-inflammatory cytokines deregulation, generating peripheral insulin resistance, which can associate with DM2, with $\beta$-cell dysfunction occurring. One of the genes that have been 
explored in this sense in the Mexican population is the TJP1 gene, which encodes type 1 tight junction, which in turn participates in cell-cell contacts and is important in pancreatic morphogenesis during embryogenesis; it also regulates the flow of nutrients, such as glucose and cholesterol, at cell apical and basolateral levels ${ }^{44}$.

\section{Theory of genetically unknown foods}

The consumption of foods the human being is nor genetically designed for can be a factor leading to the development of DM2. This hypothesis has become fashionable over the past 20 years. Evidence on this subject can be first applied to the consumption of refined sugars in sweeteners (contained in carbonated beverages), which leads to the development of hypertriglyceridemia, a risk factor for the development of DM2. On the other hand. There is a change in the type of consumption of salts contained in food: the human being is metabolically designed for potassium citrate, but many foods currently have high sodium chloride content, a type of salt we have coevolved with, but that can induce nephrosclerosis and favor kidney damage in diabetics, as it has been demonstrated in rodent models. However, potassium citrate is nephroprotector and keeps renal health safe ${ }^{8}$. This is polemic, since humans have coevolved with sodium chloride, but it also explains the high prevalence of systemic arterial hypertension that is closely associated with diabetes, which indicates that there are environmental risk factors, such as a sodium chloride-rich diet, that favor the development of vascular complications in diabetics.

In spite of current controversies around foods manufactured based on genetically modified organisms, which might be regarded as genetically unknown, there are still many open questions about the scope of the concept and its real effects. The horizontal gene transfer mechanisms are not only restricted to microorganisms, but to plants as well, thus being a "natural" transgenesis process. As an example, sweet potato (Ipomoea batatas [L.] Lam.) can be cited, a food that has traditionally been consumed for centuries in some countries of the American continent, which has been shown to have a close gene exchange relationship with Agrobacterium tumefaciens (bacteria used to generate transgenic vegetables) for thousands of years ${ }^{45}$. Nevertheless, sweet potato is and will be considered harmless by the populations that consume it and by scientific studies that reveal its benefits, as well as its known risks, for health. In contrast, studies on transgenic foods noxious effect, in particular of transgenic corn, consumed for generations, have not been fruitful or conclusive, since there is no current information in the scientific literature demonstrating their association with the development of DM2. On the contrary, a loss of objectivity, inconsistencies and possible manipulations have been observed associating them with the development of diseases regarded as global health problems ${ }^{46}$. This fact might be related to purely commercial and not scientific conflicts of interests.

On the other hand, it should be considered that the human being is designed for a basal metabolic rate of $4.18 \mathrm{MJ} / \mathrm{L}$ (the physiological limit imposed by evolution), and when consuming fat and solid-state sucrose-rich foods in excess (western diet), DM2 genesis is favored owing to an energy balance alteration. Populations that still have the thrifty genotype, such as the Pima Indians, are metabolically incapable to confront these dietary habits, which are diabetogenic for them, while other populations, such as Europeans, have managed to adapt ${ }^{47}$. The Pima Indians, as well as other populations, were metabolically shaped by low fat and energy density nutritional surroundings (thousands of years ago, during the Fourth Glaciation), where diets containing $>10-15 \%$ of fat were impossible to obtain ${ }^{47}$. An example is the fact that coronary disease mortality is 16.7 -fold higher in the USA than in rural China, where fat intake is lower and cholesterol mean concentration is $3.28 \mathrm{mmol} / \mathrm{L}$ (127 $\mathrm{mg} / \mathrm{dL}$ ), in comparison with $5.24 \mathrm{mmol} / \mathrm{L}$ (203 mg/dL). European subjects, even in spite their relative adaptation, have been reported to be unable to maintain energy balance (they gain weight) when switching from a low energy density to a high energy density diet ${ }^{48}$. This is not surprising if we consider that, when populations were hunter-gatherers, fat-rich diets were practically inexistent and, therefore, such diets can only be seen in current nutrition.

However, the effect some compounds contained in plants is partially unknown. Currently, in some populations of indigenous origin, such as southern Mexico populations, some vegetable foods, mainly in the form of extracts or infusions, are able to reduce hyperglycemic symptoms and sometimes are even considered as part of diabetes mellitus treatment.

In vitro or in vivo assays with animal models have enabled to identify that the antioxidant and inhibitory activity (phenolic and terpene compounds) of enzymes of the carbohydrate metabolism shown by 
these compounds supports their traditional use, or otherwise through the glucose-lowering chemical properties of natural foods ${ }^{49}$, which would imply that the human body has evolved together with the consumption of these foods, mainly in populations that use them as traditional treatments.

\section{Hypothesis of the ischemic origin}

On the other hand, a different pathogenesis has been reported, which explains that DM2 primary cause is of ischemic origin due to a transient or permanent blood irrigation on the anterior hypothalamic nuclei, which would elicit descendent parasympathetic pathways and anterior hypothalamus axis hyperexcitation, thus increasing blood glucose and lipid concentrations, as well as adipose tissue accumulation, with the latter being the main implicated in insulin resistance and hyperinsulinemia. Ischemia elicits chronic progressive deficiency in insulin secretion, which favors $\beta$-cell necrosis owing to a lack of irrigation. In this sense, islets have been shown to be highly dependent on blood supply, which makes then extremely vulnerable to ischemic changes $^{50}$.

\section{Syndrome of multiple organ resistance and Corkey's model}

Both in cardiac and skeletal muscle, the endothelium, hepatocyte, adipocyte and $\beta$ cell, multiple and simultaneous resistance has been reported to exist at the level of the leptin, adiponectin and insulin receptors, which translate into the coexistence of obesity, hyperphagia and $\mathrm{DM} 2^{51}$. In this sense, Corkey ${ }^{52} \mathrm{ob}$ served an excessive secretory response of $\beta$ cells, possibly owing to environmental factors or factor $X$ (fictitious), which leads to hyperinsulinemia and subsequently to insulin resistance. This secretion may also be genetically determined and hence, the factors indirectly modify redox indicators' circulating values, with increased insulin secretion, which is maintained, thus causing hepatic-origin insulin resistance and body mass increase, and subsequently the development of $D M 2^{52}$. One of the genes that is worthwhile exploring in the sense of the hypothesis is ATXN2, since it has many simultaneous pleiotropic effects on different tissues, and its dysfunction in rodent models produces fatty liver, insulin resistance, obesity and neurological problems. Some polymorphisms are associated with obesity; in Mexico, we have found association of this gene with variable number of tandem repeats (VNTR) diabetes in patients whose clinical phenotype is insulin resistance and obesity.

\section{Conformational disease and its relationship with aging and oxidative stress}

Conformational diseases arise from dysfunctional proteins aggregation in non-native conformations. DM2 can be defined as a conformational disease because one $\beta$-cell constituent protein, islet amyloid polypeptide, suffers a change on the tertiary structure, followed by self-association and tissue deposition ${ }^{53}$. On one hand, DM2 is associated with several metabolic disorders that result in excessive production of ROS and oxidative stress. These ROS set a series of redox reactions in motion, which can result in unstable nitrogen and thiol that contribute to additional redox stress ${ }^{53}$. The ability of a cell to confront ROS and oxidative stress requires functional chaperons, production of antioxidants, degradation of the protein and a cascade of intracellular events collectively known as unfolded protein response. $\beta$ cells are known to be particularly susceptible to disturbances in this quality control system, and ROS are known to play an important role in the development or progression of $\mathrm{DM}^{53}$. Oxidative stress and insulin production contribute to endoplasmic reticulum stress increase, to protein unfolding and to unfolded protein response. Since the cell quality control system is overwhelmed, intermediate islet amyloid polypeptide changes and stable oligomers with $\beta$ folded sheet antiparallel crossed structure generation are produced, which eventually accumulate as space-occupying lesions within the islets ${ }^{54}$.

In principle, dysfunctions of different organs, such as the pancreas, can be regarded as being the result of a decrease in the number of cells, a fact that Hayflick $^{54}$ documented when observing that human fibroblasts had a limited replication capability in vitro; however, diverse studies refuse that behavior as regards cell aging process cannot be replicated in whole animals (especially in superior vertebrates) ${ }^{55}$.

DM2 has been reported as a conformational disease, associated with the structural transition of physiologic proteins with intermediate stages or of pathologic proteins. It is possible that the relentless nature of progression of this disease can be 
understood with regard to the progressive accumulation of aberrant proteins or proteins that are unknown for the body, as it can be appreciated in other conformational diseases such as Alzheimer, those produced by prions or Parkinson, among others. However, when speaking about the relationship of aging with the above-mentioned pathological processes and those related to a decrease in biological processes, such as structural isomer metabolism, it is difficult, in many forms, being able to separate within them the effect adaptability and resistance to stress have, as well as the diminution of the body to be able to maintain biological functions in balance. Several authors propose a number classifications as regards theories about factors that produce aging. In this manuscript, those which might provide an explanation of the genesis regarding the process of insulin pancreatic $\beta$-cell production decrease have been addressed. In the Mexican population, specifically in type 2 diabetics with $\beta$-cell dysfunction and insulin secretion defect, we analyzed the effect of TJP1 gene p.A13344 polymorphism, which produces a conformational change type 1 tight junction, which is highly important for pancreatic morphogenesis in the embryonic period and maintains $\beta$ cells percentage and function in the adult ${ }^{56}$.

\section{Exogenous theories}

Among the theories that support a decrease in $\beta$ cell functioning, there is one about advanced glycation end-products (AGEs). In uncontrolled DM2 there is an increase in the amount of $\mathrm{AGES}^{57}$ (a phenomenon Strehler ${ }^{58}$ referred to as progressive). Owing to AGEs increase, arterial elasticity is modified, with a decrease in collagen solubility and an increase in retinal basement membranes' thickness, with intertwining of polymers such as melanoidins (generated by fructosamine) and protein chains being established ${ }^{57}$.

The oxidative stress theory, where free radicals are protagonists, propose there is $\beta$ cell progressive destruction secondary to oxidation and metabolism processes generated by anion radicals, hydroxyl radical, superoxide $\left(\mathrm{O}_{2}^{-}\right)$and hydrogen peroxide $\left(\mathrm{H}_{2} \mathrm{O}_{2}\right)$. These are part of the ROS levels, with mitochondrion being sensitive to their accumulation ${ }^{59}$, which is why insulin production will decrease, initially originating an increase in postprandial glucose and elevating the level of $A G E s^{60,61}$. However, the ROS accumulation theory is currently arguable, since, in Caenorhabditiselegans, life expectancy and longevity main determinant has been shown to be extracellular $\mathrm{Cu} /$ ZnS-dependent superoxide dismutase ${ }^{62,63}$. In this sense, we have proposed the CSB gene, which participates in the DNA repair system coupled to transcription. Its dysfunction produces a disease known as Cockayne syndrome (progeria), which includes diabetes mellitus; this can be related with melatonin secondary deficiency due to pineal gland calcification, especially because melatonin is a powerful antioxidant. With no doubt, it is a factor that reduces longevity and increases oxidative stress. We are still exploring it in middle-age and old adult diabetes in Mexico ${ }^{64}$.

In recent studies, hormesis has also been addressed, which refers to biphasic or adaptive effect by means of which low concentrations of certain toxic molecules have positive effects on genes of response to ROS, and high doses are inhibitory, sustaining that certain level of oxidative stress is necessary to prolong life expectancy ${ }^{63}$.

\section{Genic and mixed theory}

This theory proposes that aging is due to factors related with the cell genome; there are more than 100 genes that are closely related to longevity. Aging has been suggested to be produced by alterations in the DNA, or in the transcription to mRNA, or in the translation to proteins, indicating that it is a process programmed in the genome since birth and that is affected by exposure to external agents ${ }^{55,65,66}$.

A relationship has been suggested to exist between cellular aging and mitochondrial genome instability by a mitochondrial-repair decrease effect caused by ROS, which would generate inability to synthetize ATP (and important compound for insulin generation, since it is an energy dependent synthesis), thus resulting in functioning senescence and triggering $\mathrm{DM} 2$ in ensuing years ${ }^{67}$. This fact was demonstrated by Fleming et al. ${ }^{68}$ with their intrinsic mitochondrial mutagenesis hypothesis, reporting that mtDNA damage leads to internal membrane inadequate protein synthesis; this is owing to the fact that it lacks histones and appropriate repair mechanisms. However, different authors indicate that mitochondrial repair mechanisms have been identified, including the repair pathway by basement splitting, although recent works have demonstrated that it is not that efficient in mammal mitochondria, and that there are also signs of the presence of more complex repair processes ${ }^{68-70}$. Therefore, 
understanding the mtDNA-repair processes in mammals is a current challenge and is likely to lead to the elucidation of the etiology of common mutations and deletions, which are thought to be the causes of several human disorders, such as DM2 and the aging phenotype.

\section{Theory of waste products accumulation}

These are generated in the cellular aging process, and they originate in a rupture of cytoplasmic products that are deleterious for the cell, which causes for cells to be able to avoid their mortality, growing and diluting these waste products. Sheldrake ${ }^{71}$ proposed lipofuscin as a deleterious product. One of the compounds that has been the subject of various debates on whether it is cytotoxic for $\beta$ cells is the amyloid peptide or amylin. It has been profusely debated whether the presence of amyloid substance deposits can be involved in the pathogenesis of DM2, or if it's simply a consequence of the disease. However, the fact that these deposits in patients with DM2 are associated with a reduction in the numbers of $\beta$ cells suggests that they can constitute an important etiopathogenic factor in the development of insulin insufficient production $^{71,72}$.

Amyloid peptide circulates in plasma at minimal (picomolar) concentrations, with quantities varying between non-diabetic individuals (from 2 to $13 \mathrm{pmol} / \mathrm{L}$ ) and individuals with DM2 (5-17 pmol/L) and obesity ${ }^{73,74}$; however, these increases occur at DM2 initial stages and decrease in parallel with insulin secretion when DM2 is advanced ${ }^{75}$. In the ageing process, amyloid peptide deposits have been found to increase with age and to be related to decreased glucose sensitivity ${ }^{76}$, since the formation of amyloid deposits in vivo is associated with a decrease of $40 \%$ to $50 \%$ in cell function reduction in $\mathrm{DM}^{77}$. This sensitivity decrease is related to secretion of the peptide, which occurs in parallel to changes in insulin secretion, which indicates that changes in this amylin/insulin molar ratio might be involved in the development of DM2 $2^{76-78}$.

Amylin toxicity is produced by $\beta$ cells apoptotic induction by forming ionic channels, mainly calcium-permeable, which generates an intracellular flow, where the increase in amylin production by exogenous stimulation contributes to apoptosis ${ }^{79,80}$. Another theory indicates that apoptosis would be generated by an increase in apoptosis-promoting genes $p 53$ and $p 21$ expression ${ }^{81}$, which is why it is suggested that treatments with sulfonylureas elevate amylin postprandial concentrations, and that this increase is responsible for generating amyloid fiber deposits and for cell function deterioration ${ }^{82}$, something that doesn't occur with treatments that decrease hepatic glucose production or with insulin or $\operatorname{diet}^{83,84}$.

\section{Considerations for specialist physicians and public health experts}

Type 2 diabetes mellitus remains a health problem in the entire world and especially in Mexico. Its nature is complex, given the multiple molecular triggering mechanisms (more than 50 pathways implicated), which is why the health specialist should not only understand the polygenic nature of DM2, but should also explore the multiplicity of environmental risk factors, both with an additive effect that increases the risk or predisposition for diabetes, as well as its chronic complications, in order to be able to establish preventive and predictive measures for this disease in high-risk vulnerable groups.

For this, epidemiological studies are required in order to establish the percentage of disease that is determined by genes and by the environment. The interaction of factors is also complicated, and hence the analysis of all existing theories and hypotheses on DM2 etiology enables a closer approach to the genesis of the disease.

However, the multiplicity of theories cannot be applied to all populations owing to the variance in each ethnic group. Further studies are required in order to estimate how much do they contribute to the risk for development of the disease, with this being the challenge faced by health from the perspective of molecular epidemiology in the postgenomic era.

\section{References}

1. Cases A. Enfermedad macro y microvascular en la diabetes mellitus tipo 2. Nefrologia (Madr). 2002;13:406-11.

2. Trout GO. Epidemiología de la diabetes mellitus y enfermedad cardiovascular. Duzary. 2007;4:84-94.

3. Organización Mundial de la Salud, Federación Internacional de Diabetes. ¡Actuemos ya! contra la diabetes. Organización Mundial de la Salud (OMS), Federación Internacional de Diabetes; 2003. p. 1-19.

4. Organización Panamericana de la Salud. La diabetes en las Américas. Organización Panamericana de la Salud. Boletín epidemiológico. 2011;22:1-2.

5. Alvarado C, Milian SF, Valles SV. Prevalencia de diabetes mellitus e hiperlipidemias en indígenas otomíes. Salud Pública Mex. 2001;43:459-63.

6. Carrasco E, Pérez F, Ángel B, et al. Prevalencia de diabetes tipo 2 y obesidad en dos poblaciones aborígenes de Chile en ambiente urbano. Rev Méd Chile. 2004;132:1189-97.

7. Flores LJ, Ramírez SA, Durán P, et al. Molecular heterogeneity of type 2 diabetes mellitus in Mexican Population and its impact of the public health on policies in primary care. Med Chem. 2014;4:791.

8. Ramírez SA, Cabrera CE, Huacuja L, et al. Implicaciones en la atención primaria en salud de la genética y genómica en la diabetes mellitus tipo 2. Rev Med Inst Mex Seguro Soc. 2013;51:e6-26. 
9. López F. Diabetes En: López F, editor. Epidemiología: enfermedades transmisibles y crónico degenerativas. México, D.F.: Manual Moderno; 2004. p. 307-24.

10. Masa OJ. Endocrinología molecular: diagnóstico molecular. En: Masa OJ, editor. Diagnóstico molecular. En: Medicina. México, D.F : Manual Moderno; 2004. p. 198-208.

11. Ariza AR, Nazar RN. Diabetes mellitus y nutrición. En: Casanueva E, Kaufer-Horwitz M, Pérez AB, et al., editores. Nutriología médica. México, D.F.: Médica Panamericana; 2004. p. 371-84

12. Gungor N, Hannon T, Libman I, et al. DM2 en jóvenes: el cuadro completo hasta la fecha. Pediatr Clin N Am. 2005;52:1579-609.

13. Libman I. Epidemiología de la diabetes mellitus en la infancia y adolescencia: tipo 1, tipo 2 y ¿diabetes "doble"? Rev Argent Endocrinol Metab. 2009:46:22-36.

14. Landeros EA. El panorama epidemiológico de la diabetes mellitus. Revista Mexicana de Enfermería Cardiológica. 2000;8:56-9.

15. López M, Carmona A. La transición alimentaria y nutricional: un reto en el siglo XXI. An Venez Nutr. 2005:18:90-104

16. Ariza AR, Álvarez CT. Prescripción de agentes orales a pacientes con diabetes mellitus tipo 2. Guía de tratamiento. Rev Med Int Mex. 2008; 24:52-8.

17. Secretaria de Salud. Norma Oficial Mexicana, NOM-015-SSA2-2010, para la prevención, tratamiento y control de la diabetes mellitus. Diario Oficial de la Federación. México: Secretaria de Salud; 2001.

18. Rosales RC, López JJ, Núñez NY, et al. Type 2 diabetes nephropathy: a thresholds complex trait and chromosomal morbid map. Rev Med Inst Mex Seguro Soc. 2010;48:521-30.

19. Carrillo C, Panduro A. Genética de la diabetes mellitus tipo 2. Invest Salud. 2001:3:27-34.

20. Neel JV. Diabetes mellitus: a "thrifty" genotype rendered detrimental by "progress"? Am J Hum Genet. 1962;14:353-62.

21. Flores LJ, Dávalos NO, García D, et al. El polimorfismo (CAG)n del gen atxn2, nuevo marcador de susceptibilidad para diabetes mellitus tipo 2 . Rev Panam Salud Publica. 2016;40:317-23.

22. Ramírez SA, Carrillo C. Detección molecular de una variante en la secuencia del gen hpse que codifica para el dominio del sitio activo de heparanasa y el desarrollo de insuficiencia renal en pacientes con diabetes mellitus tipo 2. Bioquimia. 2009;4:58.

23. Carrillo C, González M, Ramírez SA. Detección molecular de una variante de secuencia del gen que codifica para megalina y el desarrollo de insuficiencia renal causada por diabetes mellitus tipo 2. Bioquimia. 2009;34:59.

24. Topete LR, Ramírez SA, Charles C et al. Polymorphism g.37190613 $\mathrm{G}>\mathrm{A}$ of the ELMO1 gene in the Mexican population: potential marker for clinical-surgical pathology. Cir Cir. 2014;82:402-11.

25. Valenzuela BA. Why we eat what we eat? Rev Chil Nutr. 2011;38:198-209.

26. Konrad H, German P. Nutrición. Texto y atlas. México D.F.: Médica Panamericana; 2005. p. 342-7.

27. Schnell M, Domínguez ZA, Carrera C. Aspectos genéticos, clínicos y fisiopatológicos del síndrome metabólico. An Venez Nutr. 2007:20:92-8.

28. Chacín M, Rojas J, Pineda C, et al. Predisposición humana a la obesidad, síndrome metabólico y diabetes: el genotipo ahorrador y la incorporación de los diabetogenes al genoma humano desde la antropología biológica. Síndrome Cardiometabólico. 2011;1:11-25.

29. Barker DJP. Fetal and infant origins of disease. Eur J Clin Invest. 1995;25:457-63.

30. Lucas A. Programming by early nutrition in man. En: Bock GR, Whelan J, editores. The childhood environment and adult disease. CIBA Foundation Symposium 156. Chichester: John Wiley and Sons; 1991. p. 38-55.

31. Barker DJ, Bull AR, Osmond C. Fetal and placental size and risk of hypertension in adult life. BMJ. 1990;301:259-63.

32. First World Congress Fetal Origins of Adult disease. Pediatr Res. 2001:50:1-66

33. Cordero $\mathrm{P}$, Milagro $\mathrm{Fl}$, Campion J, et al. Epigenética nutricional: una pieza clave en el rompecabezas de la obesidad. Rev Esp Obes. 2010; 8:10-20.

34. Fleisch AF, Wright RO, Baccarelli AA. Environmental epigenetics: a role in endocrine disease? J Mol Endocrinol. 2012;49:61-7.

35. Stocker CJ, Arch JR, Cawthorne MA. Fetal origins of insulin resistance and obesity. Proc Nutr Soc. 2005;64:143-51.

36. Bjornsson HT, Sigurdsson MI, Fallin MD, et al. Intra-individual changeover time in ADN methylationwith family alclustering. JAMA. 2008; 299:2877-83.

37. Martínez JA, Cordero P, Campión J, et al. Interplay of early-life nutritional programming on obesity, inflammation and epigenetic outcomes. Proc Nutr Soc. 2012;71:276-83.

38. Wren JD, Garner HR. Data-mining analysis suggests an epigenetic pathogenesis for type 2 diabetes. J Biomed Biotechnol. 2005;2:104-12.

39. Milagro FI, Mansego ML, De Miguel C, et al. Dietary factors, epigenetic modifications and obesity outcomes: progresses and perspectives. Mol Aspects Med. 2013;34:782-812.

40. Keating ST, El-Osta A. Chromatin modifications associated with diabetes. J Cardiovasc Transl Res. 2012;5:399-412.
41. Begum G, Stevens A, Smith EB, et al. Epigenetic changes in fetal hypothalamic energy regulating pathways are associated with maternal under nutrition and twinning. FASEB J. 2012;26:1694-703.

42. Ribel R, Fraga MF, Jacobsen $S$, et al. Genome-wide analysis of DNA methylation differences in muscle and fat from monozygotic twins discordant for type 2 diabetes. PLoS One. 2012;7:e51302.

43. Volkmar M, Dedeurwaerder S, Cunha DA, et al. DNA methylation profiling identifies epigenetic dysregulation in pancreatitis lets from type 2 diabetic patients. EMBO J. 2012;31:1405-26.

44. Madrigal-Ruiz P, Dávalos-Rodríguez NO, Ramírez-García SA, et al. Polymorphism p.D1134A of the TJP1 in population with Zapotec ancestry: a marker for potential thyroid cancer and other neoplasms. Revista Médica MD. 2015;7:20-6

45. Kyndt T, Quispea D, Zhaic $H$, et al. The genome of cultivated sweet potato contains Agrobacterium T-DNAs with expressed genes: an example of a naturally transgenic food crop. Proc Natl Acad Sci USA. 2015; 12:5844-9.

46. Seralini GE, Clair E, Mesnage R, et al. RETRACTED: long term toxicity of a Roundup herbicide and a Roundup-tolerant genetically modified maize. Food Chem Toxicol. 2012;50:4221-31.

47. Baschetti R. Genetically unknown foods or thrifty genes? Am J Clin Nutr. 1999;70:420-5.

48. Stubbs RJ, Johnstone AM, O'Reilly LM, et al. The effect of covertly manipulating the energy density of mixed diets on ad libitum food intake in 'pseudo free-living' humans. Int J Obes Relat Metab Disord. 1998; 22:980-7.

49. Castro CJ, Villa N, Ramírez SA, et al. Uso medicinal de plantas antidiabéticas en el legado etnobotánico oaxaqueño. Revista Cubana de Plantas Medicinales. 2014;19:101-20.

50. Rafael H. Etiología y fisiopatología de la diabetes mellitus tipo 2. Revista Mexicana de Cardiología. 2011;22:39-43.

51. Godínez SA, Valerdi L. Obesidad: resistencia endocrina múltiple. Rev Endocr Nutr. 2012;20:152-68.

52. Corkey BE. Banting lecture 2011. Hyperinsulinemia: cause or consequence? Diabetes. 2012;61:13-4

53. Hayden MR, Tyagi SC, Kerklo MM, et al. Type 2 diabetes mellitus as a conformational disease. JOP. 2005;6:287-302

54. Hayflick M. The serial cultivation of human diploid cell strains. Exp Cell Res. 1961;25:585-892.

55. López JM, Rodríguez D. Mecanismos de envejecimiento celular. Nefrologia (Madr.).1997;17(Supl 3):15-7.

56. Ramírez SA, Flores LJ, Topete LR, et al. High frequency of ancestral allele of the TJP1 polymorphism rs2291166 in Mexican population, conformational effect and applications in surgery and medicine. Cir Cir. 2016;84:28-36.

57. Gershman, R, Gilbert, DL, Nye SW, et al. Oxygen poisoning and x-irradiation: a mechanism in common. Science. 1954;119:623-6.

58. Strehler BL. Ageing: concepts and theories. En: Viidik A, editor. Lectures on gerontology. Academic Press, University of Michigan; 1982. p. 1-7.

59. Quiles JL, Ochoa JJ, Huertas JR, et al. Aspectos mitocondriales del envejecimiento. Papel del tipo de grasa de la dieta y el estrés oxidativo. Endocrinol Nutr. 2004;5:107-20.

60. Cerami A. Hypothesis: glucose as mediator of aging. J Am Geriatr Soc. 1985;33:626-32.

61. Kohn RR, Schnider SL. Glycosylation of human collagen. Diabetes. 1981;31(Supl):47-52.

62. Gems D, Partridge L. Genetics of longevity in model organisms: debates and paradigm shifts. Annu Rev Physiol. 2013;75:621-44.

63. Doonan R, Mc Elwee JJ, Matthi F, et al. Against the oxidative damage theory of aging: superoxide dismutases protect against oxidative stress but have little or no effect on life span in Caenorhabditis elegans. Genes Dev. 2008;22:3236-41.

64. Flores LJ, Ramírez SA, Núñez NY. The metabolic and molecular bases of Cockayne syndrome. Rev Invest Clin. 2010;62:480-90.

65. Slagboom PE, Vug J. Genetic instability and aging: theories, facts, and future perspectives. Genome. 1989;31:373-85.

66. Mozzhukhina TG, Chabanny EL, Levitzky EL, et al. Age-related changes of supranucleosomal structures and DNA-synthesizing properties of rat liver chromatin. Gerontology. 1991;37:181-6.

67. Miquel J, Fleming JE. A two-step hypothesis on them mechanism of in vitro cell aging cell differentiation followed by intrinsic mitochondrial mutagenesis. Exp Gerontol. 1984;19:31-6.

68. Fleming JE, Miquel J, Cottrell SF, et al. Is cell aging caused by respiration dependent injury to the mitochondrial genome? Gerontology. 1982;28:44-53.

69. Croteau DL, Stierum RH, Bohr VA. Mitochondrial DNA repair pathways. Mutation Research/DNA Repair. 1999;434:137-48.

70. Bohr VA, Anson RM. Mitochondrial DNA repair pathways. J Bioenerg Biomembr. 1999;31:391-8.

71. Sheldrake AR. The ageing, growth, and death of cells. Nature. 1974; 250:381-5.

72. Rojas I, Novials A. Amilina: del estudio molecular a las acciones fisiológicas. Rev Endocrinol Nutr. 2001;48:234-45. 
73. Hartter E, Svoboda T, Ludvik B, et al. Basal and stimulated plasma levels of pancreatic amylin indicate its co-secretion with insulin in humans. Diabetologia. 1991;34:52-4.

74. Enoki S, Mitsukawa T, Takemura J, et al. Plasma islet amyloid polypeptide levels in obesity, impaired glucose tolerance and non-insulin-dependent diabetes mellitus. Diabetes Res Clin Pract. 1992;15:97-102.

75. Kahn SE, Verchere CB, Andrikopoulos S, et al. Reduced amylin release is a characteristic of impaired glucose tolerance and type 2 diabetes in Japanese Americans. Diabetes. 1998;47:640-5.

76. Stridsberg M, Sandler S, Wilander E. Cosecretion of islet amyloid polypeptide (IAPP) and insulin from isolated rat pancreatic islets following stimulation or inhibition of $\beta$ cell function. Regul Pept. 1993;45:363-70.

77. Röcken C, Linke RP, Saeger W. Immunohistology of islet amyloid polypeptide in diabetes mellitus: semi-quantitative studies in a postmortem series. Virchows Arch A Pathol Anat Histopathol. 1992; 421:339-44.

78. Novials A, Sarri Y, Casamitjana R, et al. Regulation of islet amyloid polypeptide in human pancreatic islets. Diabetes. 1993;42:1514-9.
79. Mirzabekov TA, Lin MC, Kagan B. Pore formation by the cytotoxic islet amyloid peptide amylin. J Biol Chem. 1996;271:1988-92.

80. Bai JZ, Saafi EL, Zhang S, et al. Role of Ca2+ in apoptosis evoked by human amylin in pancreatic islet $\beta$-cells. Biochem J. 1999;343:53-61.

81. Zhang S, Liu J, Saafi EL, et al. Induction of apoptosis by human amylin in RINm5F islet beta-cells is associated with enhanced expression of p53 and p21WAF1/C1P1. FEBS Lett. 1999;455:315-20.

82. Rachman J, Payne MJ, Levy JC, et al. Changes in amylin and amylin-like peptide concentrations and $\beta$-cell function in response to sulfonylurea or insulin therapy in NIDDM. Diabetes Care. 1998;21:810-6.

83. Lindström $T$, Leckström $A$, Westermark $P$, et al. Effect of insulin treatment on circulating islet amyloid polypeptide in patients with NIDDM. Diabet Med. 1997;14:472-6.

84. Zapeçka B, Czyzyk A, Dworak A, et al. Treatment with metformin in NIDDM patient's lowers plasma amylin level. Diabetologia. 1997;40(Supl 1):A316. 